\title{
FACTORS INFLUENCING FINANCIAL PLANNING FOR MARRIAGE AMONGST YOUNG MALAYSIAN COUPLES
}

\author{
Joyce Hwee-Nga Koe* \\ Sunway University Business School \\ Ken Kyid Yeoh \\ Nottingham University Business School
}

\begin{abstract}
Financial planning for marriage contributes to happier, more satisfying and longer-lasting unions. However, there is increasing evidence that young Malaysian couples are burdened by excessive debts and have a tendency to overspend on their wedding. Based on the Theory of Planned Behaviour, the current study investigates key factors - financial literacy, attitude towards money, attitude towards debt, financial goals and social influence - that are likely to influence the degree of financial planning for marriage undertaken by married and soon-to-be-married couples. The study also examines the mediating role of financial literacy on the relationships between the aforementioned key factors and financial planning for marriage. The study collected data from a sample of 201 respondents recruited via purposive sampling and used a bootstrapped partial least squares structural equation modelling (PLS-SEM) approach for data analysis. The results showed that (i) financial literacy positively influences financial planning for marriage; (ii) attitude towards money, financial goals and social influence positively influence both financial literacy and financial planning for marriage; (iii) attitude towards debt has a negative influence on financial planning for marriage but no influence on financial literacy; and (iv) financial literacy has a mediating effect. The findings highlight the importance of financial counselling, education as well as discipline in bringing about successful marriages.
\end{abstract}

Keywords: Financial Planning, Financial Literacy, Financial Goals, Consumer Attitudes, Attitudes Towards Money, Attitude Towards Debt.

Received: 3 January 2019

Accepted: 31 December 2020

https://doi.org/10.33736/ijbs.3161.2021

\section{INTRODUCTION}

Malaysia is a middle-income economy where the mean monthly income for urban households and rural households are approximately RM6,833 and RM3,841 respectively (Department of Statistics Malaysia, 2014). Even so, the mean household expenditure is worryingly high with $57 \%$ of urban households' mean monthly income and $77 \%$ of rural households' mean monthly income. Consumerism is strong in Malaysian society, with Malaysians wanting to own both

\footnotetext{
- Corresponding Author: Department of Economics and Finance, Sunway University Business School, Sunway University, Bandar Sunway, Selangor; Tel: +6 (03) 7491 8622; Email: joycen@sunway.edu.my
} 
essential (e.g food, basic shelters and necessities) and non-essential goods (e.g. luxury items and cars). However, many Malaysians do not have emergency savings and are burdened by excessive debts and are prone to bankruptcy (Cavalho \& Hamdan, 2015).

For Malaysian youths planning to get married and start a family, this debt burden could be a significant factor to consider. Apart from bringing personal debts into the marriage, preparations for the wedding can be an expensive affair due to the pressure of social expectations and the tendency to overspend because of easy credit availability (Lau, 2014). In this regard, Boo (2013) estimated that the costs associated with a typical wedding reception can set couples back by at least RM50,000. Although marriage should ideally enhance financial security as there will now be two productive individuals contributing to the newly-formed household income, the opposite may also be true. High personal debts accumulated prior to the marriage, coupled with added financial obligations (such as having children), can undoubtedly undermine the degrees of happiness, security, satisfaction as well as longevity of the marriage (Dew, 2011). From a financial perspective, better financial knowledge, planning and discipline would result in more financially-secure, happier and long-lasting marriages. However, to date research in this area is lacking. This forms the primary justification of the current study which aims to investigate selected aspects relating to financial planning within the context of young Malaysian couples. The current study conceptualises financial planning for marriage as being influenced by financial literacy, attitude towards money, attitude towards debt, financial goals, and social influence by using the Azjen's (1991) Theory of Planned Behaviour.

This study also incorporates discussion on a number of complementary theories such as the economic theory of marriage, the theory of assortive mating, the social expectation theory, goal setting theory and the theory of experiential learning (Bacon, Conte, \& Moffat, 2014; Becker 1974; Cropanzano \& Mitchell, 2005; Kolb, 1984; Vroom, 1964).

\section{LITERATURE REVIEW}

\subsection{Financial Planning for Marriage}

Traditionally, marriage is a core social institution across most, if not all, societies worldwide as it is the basis for forming households. The economic theory of marriage describes the potential financial gains of marriage from the perspective of children, division of labour, pooling of joint resources and risk of partners/spouses (Becker, 1973). From a financial planning perspective, the degree of trust and informal mutual communication within a marriage may either facilitate the management of finances or promote free-riding. Marriage partners are often not equally endowed in financial resources and have different spending habits. Depending on the level of fiscal trust, there may be hidden agendas and undisclosed financial histories between the spouses in terms of debt burden (Loftus, 2004). If partners are perceived as not contributing towards household expenses, a feeling of unfairness and distrust may arise. Research has found that financial planning such as having a budget and proper debt management are necessary for couples to have stronger and happier martial bonds (Skogrand, Johnson, Harrocks, \& DeFrain, 2011). Additionally, having sufficient financial assets lessens the likelihood of divorce (Dew, 2011). Based on the above, it appears that proper financial planning may be necessary for happier marriages. 
The act of getting married itself is usually very costly. This is partly due to tradition where couples strive to live up to social expectations and demands (Jiang, Zhang, \& Sànchez-Barricarte, 2015). In Malaysia for instance, the Malays would customarily negotiate "bride-prices" ranging from RM2,000 to RM30,000 (Johari, 2014) while the Chinese expect "auspicious" numbers for bride-prices such as RM1,888 to RM 8,888 ("8" is regarded as an auspicious number) (Tse, 2015). Without proper financial planning, the escalating costs of wedding ceremonies and the conspicuous lure of personal loans can create additional long-term marriage debts apart from those incurred pre-marriage. Further compounding these issues is the fact that the topic of money is traditionally a major taboo topic alongside religion, politics, health and death (Taylor, 2014). This is because possessing a huge amount of money communicates the perception of greed, may cause others to be envious and in some situations, raises superstitions surrounding the fear of losing money (Furnham, 2014). As such, issues surrounding money and personal finance are often avoided in courtship, resulting in potential conflict during marriage (Britt \& Huston, 2012; Furnham, 2014).

In the current study, financial planning for marriage is defined as initiatives taken by individuals to communicate about money management matters (e.g. wedding costs, post-marriage future savings, spending, budgeting, etc.). In Malaysia, studies have found that couples seem to exhibit some aspects of bargaining power in a marriage, with women having more control over everyday household expenses while men have more charge over large household expenses (Yusof, 2015; Yusof \& Duasa, 2010). Financial problems have consistently been linked to marital stress and a major contributor to divorces in Malaysia (Jay, 2019). The perception of "irresponsible" spending behaviour among spouses in itself has been found to cause marriage conflicts (Britt, Hill, LeBaron, Lawson \& Bean, 2017). While it is not guaranteed that all financial problems can be avoided, financial management has been posited to increase long-term marital satisfaction (Kerkmann, Lee, Lown, \& Allgood, 2000).

In the area of financial planning, Azjen's (1991) Theory of Planned Behaviour (TPB) has been used to research on credit card spending behaviours, attitude towards money and intention to adopt Takaful insurance (Shahab, Husin \& Husin, 2017; Nga \& Yeoh, 2015; Sari \& Rofaida, 2011; Xiao, Tang, Serido. \& Shim, 2011). This study extends the TPB framework by investigating the influences of personal attitudes (i.e. attitude towards money, attitude towards debt and financial goals), Subjective norms (i.e. social influence) and perceived behavioural control (i.e. financial literacy) on the intention to pursue financial planning for marriage.

\subsection{Financial Literacy}

Financial literacy includes the awareness, knowledge and competencies required to exercise wise financial planning with the intention of improving financial well-being (Hussain \& Sajjad, 2016; Murugiah, 2015). It includes knowledge on income and expense management (i.e. budgeting), design savings and debt management plans, as well as awareness of the time compounding value of money (Idris, Yazid, Faique, Daud, Ismail, Bakri \& Taib, 2016). At the intermediate level, financial literacy incorporates the concepts of risks and returns of investment for wealth accumulation (e.g. shares and unit trusts).

Kolb's (1984) theory of experiential learning stipulates that an individual acquires knowledge via experiences (e.g. actual participation in budgeting), observations (e.g. role models) and 
conceptualisations (e.g. formal education). Hence, financial literacy can be measured objectively (i.e. testing of technical knowledge via numerical/mathematical quizzes) or subjectively (i.e. personal self-assessment of knowledge self-efficacy in making informed money-related judgments). The current study adopts a subjective measurement approach as financial literacy measured subjectively has been found to significantly influence both long and short-term financial behaviours (Henager \& Cude, 2016). Overall, financial literacy has a positive influence on financial satisfaction (Hussain \& Sajjad, 2016; Xiao, Chen, \& Chen, 2014). In lower income groups, financial education has been found to increase the likelihood of savings and savings goal attainment (Grinstead, Mauldin, Sabia, Koonce, \& Plamer, 2011). However, higher education, higher financial knowledge and prudent financial behaviour and attitude do not necessarily lead to better financial planning (Loke, 2013).

With the rapidly rising cost of living and improved longevity, Malaysians are facing immense challenges in coping with inflation and ensuring sufficiency of household savings. Besides that, as financial markets become more complex, the lack of financial literacy and the struggle to make ends meet have made many Malaysians easy victims of financial scams involving illegal foreign exchange, African love dating, travel, investments and get-rich-quick schemes (Bank Negara Malaysia, 2017; Joflin, 2017; Kaur, 2016; Shah, 2016). Past studies found that financial satisfaction can be improved by the strengthening of financial knowledge (Joo \& Grable, 2004). Financial literacy/education is acquired at individual level but decision making is often made at family level (Kim, Gutter \& Spangler, 2017). Thus, the respective spouses' opinions on financial decision making issues remain relevant. In line with TPB, financial literacy (acting as proxy for intention) should theoretically have an impact on financial planning behaviour. Hence:

\section{$H_{1}$ : Financial literacy has a positive influence on financial planning for marriage.}

\subsection{Attitude Towards Money}

The meaning of money extends beyond its use as a medium of exchange. Money often communicates the strength and direction of social ties, status, power and other underlying attitudes of an individual towards it (Baker \& Jimmerson, 1992). Attitude towards money is shaped through values, beliefs and acculturation within society, and has been documented in frameworks that include power-prestige, retention, distrust and anxiety (Nga \& Yeoh, 2015; Shih \& Ke, 2013; Yamauchi \& Templer, 1982). The current study explores the power-prestige dimension which includes success and materialism (Yamauchi \& Templer, 1982).

From an individualistic perspective, the theory of symbolic self-completion posits that an individual will seek to fill his/her perceived inadequacy in competencies by committing himself/herself to self-defining goals, symbols of completeness and perceived social realities (Gollwitzer \& Wicklund, 1982; Higgins, 1987). In the age of social media, materialistic attitudes are reflected in conspicuous purchasing behaviours designed to achieve a desired social image/status. Indeed, materialism has been found to positively influence impulsive non-essential spending and the purchase intention of luxury fashion goods (Kamal, Chu, \& Pedram, 2013; Penman, 2008), particularly among young consumers (Durvasula \& Lynsonski, 2010). In the context of marriage, materialistic attitudes towards money may cause newlyweds to splurge on their wedding reception and lead indulgent lifestyles to the extent of incurring excessive debt 
(Boo, 2013). As such, in line with Azjen's (1991) TPB, an individual's attitude towards money influences his/her motivation to pursue financial literacy.

Alternatively, the theory of assortive mating suggests that men and women tend to marry partners with similar characteristics (besides income effects), such as in education, age and physical capital, to promote economic stability and marriage longevity (Bacon et al., 2014; Becker, 1974). Hence, prospective marriage partners have become increasingly selective of economically endowed persons over time (Painter \& Vespa, 2012). Greater opportunities for women in the labour market over the decades have reduced the gap in income inequality. Consequently, many newly engaged or wedded couples are beginning to question if their partners are only marrying for money (Young \& O'Neill, 1992). Besides this, marriage has been found to be positively associated with wealth accumulation as spouses could gain from economies of scale, dual incomes and financial transfers over time (Nash, 2008; Painter \& Vespa, 2012; Zissimopoulos, Karney, \& Rauer, 2015). Higher wealth effects may lead to a more materialistic attitude towards money, which in turn may influence an individual's intention to pursue financial literacy and improve his/her current wealth accumulation ability and social image. Hence:

\section{$H_{2 a}$ : Attitude towards money has a positive influence on financial literacy.}

Due to inequality in skills, income and time between spouses, there may be an imbalance in power and control pertaining to the allocation and management of money as well as the breadwinner's role within a marriage (Kenney, 2006). Partners could have different attitudes towards money and spending habits that may impact their relationship satisfaction (Britt, Grable, Goff \& White, 2008). The money management system within a marriage may vary from the provision of housekeeping allowance (high dominance by one partner, usually the male) to joint money management. The social exchange theory stipulates that reciprocity will traditionally compel one party (usually the wife) to perform household tasks in exchange for economic support (Cropanzano \& Mitchell, 2005; Treas \& Dai, 2012). The difference in relative income often determines which partner takes charge of the household financial decision-making. As perceived power inequality within a marriage may subtly impact communication on financial planning, it is hypothesised that:

$H_{2 b}$ : Attitude towards money has an influence on financial planning for marriage.

\subsection{Attitude Towards Debt}

Attitude towards debt relates to an individual's values and beliefs on the use of personal borrowings as a part of one's life. In the modern world where credit is widely and easily available, many young adults hold the view that debt is a quick fix to fulfill their hedonistic lifestyle. They believe that the consumption of debt is deemed acceptable by peers and society (O'Loughlin \& Szmigin, 2016). Indeed, an individual's behavioural, cognitive and emotional attitudes towards debt have a positive influence on debt usage (Pattarin \& Cosma, 2012). Individuals with a carefree attitude towards debt would exude a short-term need of debt for survival and an inability to delay gratification. They are often guided by their emotions in spending, overconfident in their ability to service loans and are in denial of the negative consequences of their debt burden (Brown \& Woodruffe-Burton, 2015). In this regard, past research has found that newlyweds with higher solvency risk (possession of high debts) perceive 
less need for future financial planning and are less in control of their lives than other couples (Godwin, 1996).

Statistics revealed that on average, 5,000 Malaysian youths below the age of 35 are declared bankrupt annually (Bernama, 2016; Cavalho \& Hamdan, 2015). This phenomenon is attributed to the youths' inability in servicing their car, mortgage, education, and personal loans (including credit card), as well as them assuming the role of guarantors for the borrowings of others. While the increasing cost of living has reduced the disposable income of Malaysians, the debt burden is also exacerbated by lack of financial planning knowledge and discipline (Murugiah, 2015). A past study also found that Malay youth workers lack understanding and realization on the implications of their debt service burden (Idris, et. al, 2016). In addition, many Malaysians fail to set aside savings for emergencies and/or unexpected events such as medical fees and loss of job (Zaid, 2017). Furthermore, the entitlement mentality among young adults (especially millennials) instills the belief that they can rely on the endowments of their parents indefinitely to provide for their needs and wants even to the extent of debt servicing (Rourke, 2011). Hence, young Malaysians may lack the motivation to enhance their financial knowledge, which creates a false sense of security on their debt management capabilities. Hence:

\section{$H_{3 a}:$ Attitude towards debt has a negative influence on financial literacy.}

In marriage, partners may have differing opinions in terms of spending habits and debt attitudes. Spouses may have hidden agendas, allegiances, financial histories and financial boundaries when it comes to undisclosed debt (Loftus, 2004). These secrecies may breach the fiscal trust which could be more detrimental than sexual transgression (Carter, 2006; Loftus, 2004). Past research also posits that a high debt burden may be a hindrance to harmonious marriages among newlyweds, and are positively related to divorces (Dew, 2011). It is also common for newlyweds to have accumulated outstanding charge account, automobile, education and personal loans, increasing the risk of insolvency within marital finances (Godwin, 1996). Other past research suggests that couples with great marriages are frugal and maintain minimal or shunned debts (Skogrand et al., 2011). Hence:

\section{$H_{3 b}:$ Attitude towards debt has an influence on financial planning for marriage.}

\subsection{Financial Goals}

A goal is a statement of an individual's aspirations that promotes concerted effort towards achieving the desired end. In the financial planning process, financial goals refer to what individuals are saving for and how much. Financial plans stipulate how and what actions are required in terms of savings, investment and other changes in behaviour to achieve financial goals. As such, financial goals can be envisaged as providing the vision, aim and focus needed in preparing financial plans (Keown, 2014). For the goal to be effective, goal setting theory posits that an individual's financial goals need to have clarity and be adequately challenging, while the individual has sufficient commitment, frequent feedback and the ability to cope with the task complexity in achieving the intended goal (Locke, 1968; Locke \& Latham, 2002).

In practice, the financial goal setting process often stresses that goals should be Specific, Measurable, Action-Oriented, Realistic and Time-bound (Kapoor, Dlabay, \& Hughes, 2012). In 
line with this, past research found that experienced investors are often clear of their financial diversification goals and risk appetite, and are able to maintain long-term endurance and avoid herding behaviour (Ciccoletto, 2009; Robbins, 2017). Past research also acknowledges the role of financial literacy in providing practical guidance in the achievement of cash flow, credit, savings and investment goals (Mandell \& Klein, 2007).

Couples in a marriage need to communicate financial goals in a transparent manner to develop mutual trust, respect and commitment towards achieving the marriage's financial plan (Skogrand et al., 2011). Realistic household financial goals require careful consideration of the spouses' resources and the degree of perceived likelihood or control in the actual achievements. Hence:

\section{$H_{4 a}$ : Financial goals has an influence on financial literacy. $H_{4 b}$ : Financial goals has an influence on financial planning for marriage.}

\subsection{Social Influence}

Social influence is described as the likelihood of significant reference groups, such as family and friends, in exerting considerable pressure on an individual's behaviour (Azjen, 1991). The family financial socialisation model posits that family interactions help to shape one's financial attitudes, beliefs and outcomes (Danes \& Yang, 2014). The model further stresses that the highest influence of family socialisation occurs during early childhood development and the initial stages of life partnership formation. Young adults often turn to their parents as role models (O'Loughlin \& Szmigin, 2016), whose financial experience could positively influence young adults' financial knowledge acquisition (Tang \& Peter, 2015). Even so, young adults were found to be less likely to set aside emergency funds or avoid incurring debts as they are still reliant on their parents for financial support (Henager \& Cude, 2016).

Within the marriage context, social influence includes the spouse's influence. The family systems theory posits that social influence can even result in an individual's inability to differentiate himself/herself from the influence of others, leading to poor joint-decision making within a marriage (Carter, 2006). Moreover, the social exchange theory posits that the degree of interdependencies among these significant others may lead to the expectation of reciprocity (Cropanzano \& Mitchell, 2005). In Malaysia, parents have been found to be significant sources of financial support (Loke, 2013). Past studies in Malaysia have also found a significant positive influence of social networks on financial literacy and money management among students (Chung \& Park, 2014; Sunderasen, Rahman, Othman, \& Danaraj, 2016). Therefore:

\section{H5a: Social influence has a positive influence on financial literacy.}

The culture of consumerism has promoted pervasive conspicuous spending among Malaysian youths. The Veblen effect in advertising distracts rational thought and creates a demand that promotes the extroverted displays of perceived wealth (Patsiaouras \& Fitchett, 2012). Consequently, consumers are compelled to pay more for goods and services that symbolise high social status. To this extent, the concept of "kiasu" — the fear of losing out — may push individuals to pursue competitive spending behaviours driven by envy, selfishness and greed (Ho, Ang, Loh, \& Ng, 1998). Similarly, the pervasiveness of "kiasuism" in Malaysia could 
extend to the preparation for lavish weddings as well as ownership of cars and houses that promote one's social image. Hence:

\section{$H_{5 b}$ : Social influence has a positive influence on financial planning marriage.}

Figure 1: Conceptual framework of the study

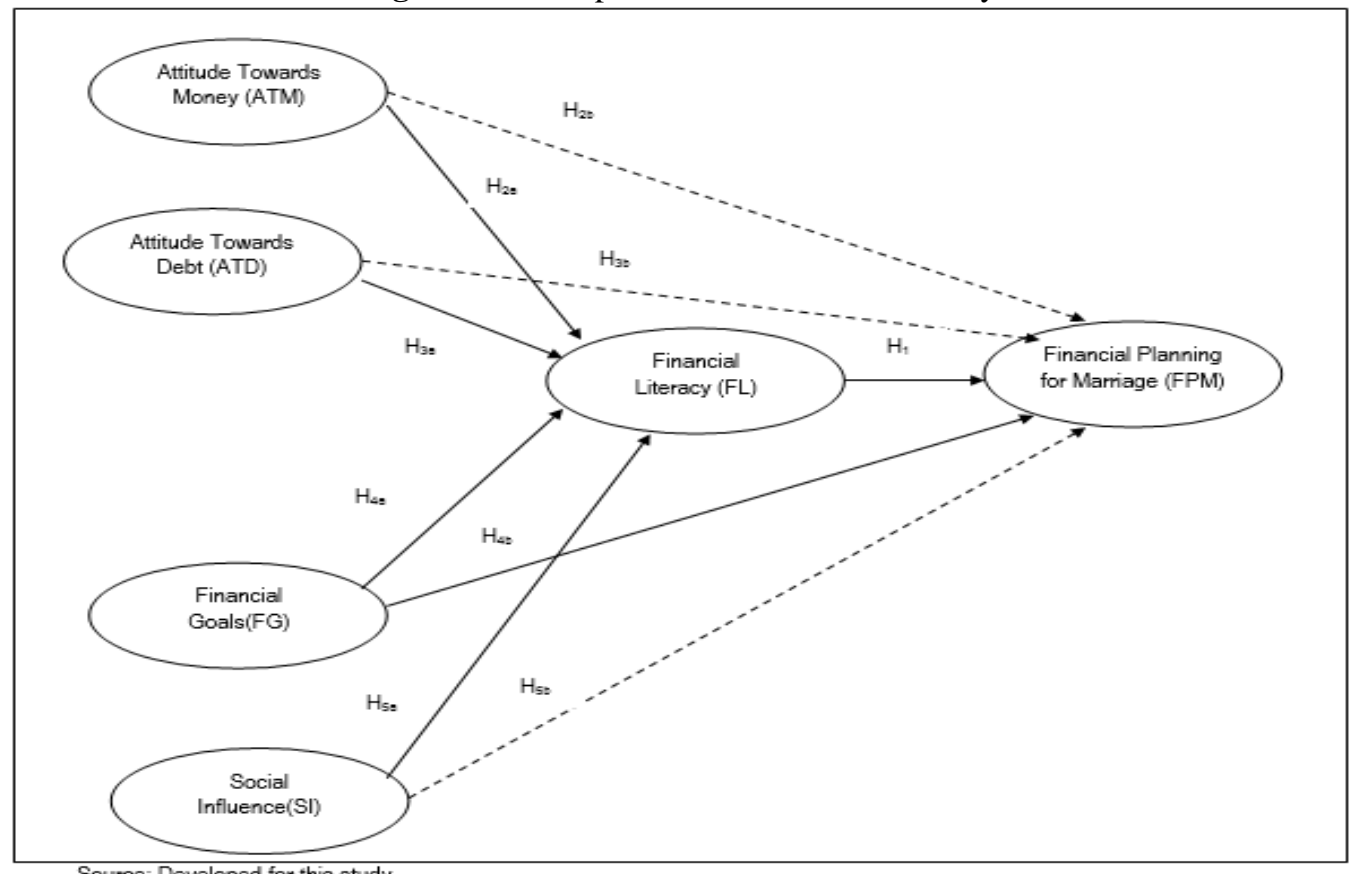

Source: Developed for this study

\section{RESEARCH DESIGN AND METHOD}

\subsection{Sampling Design and Respondents' Profile}

The current study adopted a purposive sampling design where questionnaires were distributed to both married and soon-to-be-married couples within the Klang Valley, Malaysia. The couples were selected as respondents based on the criterion that they are married (for at least a year) or planning to get married within the next 24 months. Based on the United Nations World Marriage Data in 2015, the average age of first marriage in Malaysia is 25.8 years for women and 28 years for men. Data was collected from a total of 201 respondents over a six-week period between August and September 2016. The descriptive statistics of the respondents are summarized in Table 1.

Table 1: Descriptive Statistics of respondents of the study 


\begin{tabular}{llrr}
\hline \hline & & Frequency & Percent \\
\hline Gender & Male & 107 & 53.2 \\
& Female & 94 & 46.8 \\
& Total & 201 & 100.0 \\
\hline Age & $20-24$ & 129 & 64.2 \\
& $25-29$ & 55 & 27.4 \\
& $30-34$ & 12 & 6.0 \\
& $35-39$ & 5 & 2.5 \\
& Total & 201 & 100 \\
\hline Highest Education Level & High School Graduate & 32 & 15.9 \\
& College & 46 & 22.9 \\
& Associate Degree & 9 & 4.5 \\
& Bachelor's Degree & 102 & 50.7 \\
& Post-Graduate & 12 & 6.0 \\
& Total & 201 & 100.0 \\
\hline Length of relationship & 1-2years & 115 & 57.2 \\
& 3-4years & 47 & 23.4 \\
& 5-6years & 24 & 11.9 \\
& 7 years and above & 15 & 7.5 \\
& Total & 201 & 100.0 \\
\hline \hline
\end{tabular}

\subsection{Measurement Assessment}

As indicated in Table 2, scale items used to assess the constructs were adapted from extant literature. All items were measured on a 5-point Likert scale (from $1=$ Strongly disagree to $5=$ Strongly agree). The study utilises ADANCO PLS-SEM package to analyse the measurement and structural models. PLS-SEM is suitable for exploratory studies and has a better ability to handle both formative and reflective constructs as well as smaller sample sizes (Henseler, 2018).

Table 2: Constructs of the study

\begin{tabular}{|c|c|c|}
\hline Construct & $\begin{array}{l}\text { Number } \\
\text { of items }\end{array}$ & Developed for the study based on: \\
\hline $\begin{array}{l}\text { Financial Planning for } \\
\text { Marriage (FPAM) }\end{array}$ & 7 & Nga, Yong \& Sellappan (2009) \\
\hline Financial Literacy (FL) & 8 & $\begin{array}{l}\text { Pattarin \& Cosma (2012); Nga, Yong \& Sellappan (2009); } \\
\text { Idris, et al. (2016) }\end{array}$ \\
\hline $\begin{array}{l}\text { Attitude Towards Money } \\
\text { (ATM) }\end{array}$ & 8 & Nga \& Yeoh (2015); Yamauchi \& Templar (1982) \\
\hline $\begin{array}{l}\text { Attitude Towards Debt } \\
\text { (ATD) }\end{array}$ & 7 & $\begin{array}{l}\text { Ironfield-Smith, Keasey, Summers, Duxbury \& Hudson } \\
\text { (2005); Ismail, Serguieva \& Singh (2011); O'Loughlin \& } \\
\text { Szmigin(2006) }\end{array}$ \\
\hline Financial Goal & 8 & Kapoor, et. al. (2013); Shockey \& Seiling (2004) \\
\hline Social Influence & 8 & Nga \& Yeoh (2015) \\
\hline
\end{tabular}

\section{RESULTS}


A construct's convergent reliability is supported if the composite reliability measures of DijkstraHenseler's rho $\left(\rho_{\mathrm{A}}\right)$ and Jöreskog's rho $\left(\rho_{\mathrm{c}}\right)$ are both above 0.60 (Henseler, Ringle, \& Sinkovics, 2009), and the Cronbach's alpha value is above 0.70 (Nunnally \& Bernstein, 1994). Indicator reliability is determined by absolute standardised outer loadings higher than 0.70 (Hair, Ringle, $\&$ Sarstedt, 2011). Table 2 displays the measures of reliability and convergent validity for all items. Construct's items that have item loadings below 0.60 have been removed. Based on Table 3 , it can be concluded that the remaining items have achieved acceptable thresholds.

Table 3: Reflective measurement model: Reliability and convergent validity

\begin{tabular}{|c|c|c|c|c|c|c|}
\hline Latent Construct & Indicator & $\begin{array}{c}\text { Item } \\
\text { loadings }\end{array}$ & $\begin{array}{l}\text { Dijkstra- } \\
\text { Henseler's } \\
\text { rho }\left(\rho_{\mathrm{A}}\right)\end{array}$ & $\begin{array}{l}\text { Jöreskog's } \\
\text { rho }\left(\rho_{c}\right)\end{array}$ & $\begin{array}{l}\text { Cronbach's } \\
\text { alpha }(\alpha)\end{array}$ & AVE \\
\hline $\begin{array}{l}\text { FP for } \\
\text { Marriage } \\
(\mathrm{FPM})\end{array}$ & $\begin{array}{l}\text { marriage1 } \\
\text { marriage2 } \\
\text { marriage3 } \\
\text { marriage4 } \\
\text { marriage5 } \\
\text { marriage6 } \\
\text { marriage7 }\end{array}$ & $\begin{array}{l}0.7881 \\
0.8265 \\
0.8578 \\
0.8664 \\
0.8419 \\
0.8286 \\
0.8120\end{array}$ & 0.9287 & 0.9402 & 0.9258 & 0.6922 \\
\hline $\begin{array}{l}\text { Financial } \\
\text { Literacy } \\
\text { (FL) }\end{array}$ & $\begin{array}{l}\text { literacy1 } \\
\text { literacy2 } \\
\text { literacy4 } \\
\text { literacy5 } 5 \\
\text { literacy6 } \\
\text { literacy7 }\end{array}$ & $\begin{array}{l}0.8338 \\
0.7681 \\
0.7307 \\
0.7573 \\
0.7681 \\
0.7284\end{array}$ & 0.8623 & 0.8943 & 0.8580 & 0.5855 \\
\hline $\begin{array}{l}\text { Attitude } \\
\text { Towards } \\
\text { Money (ATM) }\end{array}$ & $\begin{array}{l}\text { money1 } \\
\text { money2 } \\
\text { money7 }\end{array}$ & $\begin{array}{l}0.9012 \\
0.8792 \\
0.7722\end{array}$ & 0.8535 & 0.8884 & 0.8151 & 0.7272 \\
\hline $\begin{array}{l}\text { Attitude } \\
\text { Towards } \\
\text { Debt (ATD) }\end{array}$ & $\begin{array}{l}\text { debt4 } \\
\text { debt5 } \\
\text { debt7 }\end{array}$ & $\begin{array}{l}0.8606 \\
0.8903 \\
0.8168\end{array}$ & 0.8402 & 0.8919 & 0.8203 & 0.7335 \\
\hline $\begin{array}{l}\text { Financial Goals } \\
\text { (FG) }\end{array}$ & $\begin{array}{l}\text { goal1 } \\
\text { goal2 } \\
\text { goal3 } \\
\text { goal5 } \\
\text { goal6 } \\
\text { goal7 }\end{array}$ & $\begin{array}{l}0.7856 \\
0.7523 \\
0.7961 \\
0.8012 \\
0.7447 \\
0.7312\end{array}$ & 0.8654 & 0.8966 & 0.8617 & 0.5914 \\
\hline $\begin{array}{l}\text { Social } \\
\text { Influence (SI) }\end{array}$ & $\begin{array}{l}\text { social1 } \\
\text { social2 } \\
\text { social6 } \\
\end{array}$ & $\begin{array}{l}0.7512 \\
0.8609 \\
0.8358 \\
\end{array}$ & 0.7647 & 0.8575 & 0.7515 & 0.6680 \\
\hline
\end{tabular}

Discriminant validity is assessed using the Fornell-Larcker criterion, cross-loadings and Heterotrait-Monotrait (HTMT) criterion (Hair et al., 2011; Henseler et al., 2009; Henseler, Ringle, \& Sarstedt, 2015). Tables 4, 5 and 6 present the results of the discriminant validity tests. In Table 3, the average variance extracted (AVE) values are located along the diagonal and they are higher than the values within the same column. This indicates the highest AVE differentiating the construct named at the top of respective columns from the one's below. 
Table 4: Discriminant validity: Fornell-Larcker's criterion

\begin{tabular}{lrrrrrr}
\hline \hline Construct & 1 & 2 & 3 & 4 & 5 & 6 \\
\hline 1. FPM & $\mathbf{0 . 6 9 2 2}$ & & & & & \\
2. FL & 0.3618 & $\mathbf{0 . 5 8 5 5}$ & & & & \\
3. ATM & 0.1684 & 0.2418 & $\mathbf{0 . 7 2 7 2}$ & & & \\
4. ATD & 0.0003 & 0.0432 & 0.1013 & $\mathbf{0 . 7 3 3 5}$ & & \\
5. FG & 0.2634 & 0.4750 & 0.1523 & 0.0382 & $\mathbf{0 . 5 9 1 4}$ & \\
6. SI & 0.1749 & 0.0915 & 0.063 & 0.0006 & 0.0764 & $\mathbf{0 . 6 6 8 0}$ \\
\hline \hline
\end{tabular}

Note: Squared correlations; AVE values bolded and located along the diagonal line.

Table 5 shows that the cross-loading of each item (as represented by the values highlighted in bold) is heaviest against the construct it measures than against other constructs, supporting discriminant validity.

Table 5: Discriminant validity: Cross-loadings

\begin{tabular}{llrrrrr}
\hline \hline Indicator & FG & ATD & ATM & FL & SI & FPM \\
\hline goal1 & $\mathbf{0 . 7 8 5 6}$ & 0.1817 & 0.3158 & 0.5747 & 0.1670 & 0.3884 \\
goal2 & $\mathbf{0 . 7 5 2 3}$ & 0.2409 & 0.2483 & 0.4655 & 0.1836 & 0.3093 \\
goal3 & $\mathbf{0 . 7 9 6 1}$ & 0.0996 & 0.2917 & 0.5070 & 0.2419 & 0.4528 \\
goal5 & $\mathbf{0 . 8 0 1 2}$ & 0.0968 & 0.3096 & 0.5469 & 0.2648 & 0.4673 \\
goal6 & $\mathbf{0 . 7 4 4 7}$ & 0.1756 & 0.3673 & 0.5868 & 0.1277 & 0.3887 \\
goal7 & $\mathbf{0 . 7 3 1 2}$ & 0.1227 & 0.2517 & 0.4818 & 0.2995 & 0.3384 \\
debt4 & 0.1684 & $\mathbf{0 . 8 6 0 6}$ & 0.2608 & 0.1978 & -0.0568 & 0.0149 \\
debt5 & 0.1974 & $\mathbf{0 . 8 9 0 3}$ & 0.2478 & 0.1886 & 0.0172 & 0.0070 \\
debt7 & 0.1281 & $\mathbf{0 . 8 1 6 8}$ & 0.3265 & 0.1383 & -0.0204 & 0.0234 \\
money1 & 0.3851 & 0.2590 & $\mathbf{0 . 9 0 1 2}$ & 0.4798 & 0.2210 & 0.3627 \\
money2 & 0.3378 & 0.2151 & $\mathbf{0 . 8 7 9 2}$ & 0.4400 & 0.2523 & 0.4237 \\
money7 & 0.2578 & 0.3919 & $\mathbf{0 . 7 7 2 2}$ & 0.3101 & 0.1518 & 0.2283 \\
literacy1 & 0.5298 & 0.0883 & 0.5000 & $\mathbf{0 . 8 3 3 8}$ & 0.2663 & 0.5597 \\
literacy2 & 0.6385 & 0.2004 & 0.2789 & $\mathbf{0 . 7 6 8 1}$ & 0.2114 & 0.3534 \\
literacy4 & 0.4352 & 0.1305 & 0.4138 & $\mathbf{0 . 7 3 0 7}$ & 0.1633 & 0.4844 \\
literacy5 & 0.5757 & 0.1846 & 0.2214 & $\mathbf{0 . 7 5 7 3}$ & 0.2619 & 0.3170 \\
literacy6 & 0.5378 & 0.2017 & 0.3882 & $\mathbf{0 . 7 6 8 1}$ & 0.3580 & 0.4926 \\
literacy7 & 0.4542 & 0.1590 & 0.4234 & $\mathbf{0 . 7 2 8 4}$ & 0.1108 & 0.5257 \\
social1 & 0.2490 & 0.0678 & 0.3180 & 0.2117 & $\mathbf{0 . 7 5 1 2}$ & 0.2900 \\
social2 & 0.1667 & -0.0861 & 0.1524 & 0.2537 & $\mathbf{0 . 8 6 0 9}$ & 0.3464 \\
social6 & 0.2647 & -0.0260 & 0.1689 & 0.2710 & $\mathbf{0 . 8 3 5 8}$ & 0.3806 \\
marriage1 & 0.3994 & 0.0897 & 0.3240 & 0.4466 & 0.2749 & $\mathbf{0 . 7 8 8 1}$ \\
marriage2 & 0.3740 & -0.0083 & 0.2844 & 0.4463 & 0.4539 & $\mathbf{0 . 8 2 6 5}$ \\
marriage3 & 0.3902 & 0.0525 & 0.3828 & 0.4974 & 0.2907 & $\mathbf{0 . 8 5 7 8}$ \\
marriage4 & 0.4532 & -0.0262 & 0.4144 & 0.5371 & 0.3028 & $\mathbf{0 . 8 6 6 4}$ \\
marriage5 & 0.4811 & 0.0650 & 0.4107 & 0.5837 & 0.3567 & $\mathbf{0 . 8 4 1 9}$ \\
marriage6 & 0.4517 & -0.0041 & 0.3095 & 0.5234 & 0.3507 & $\mathbf{0 . 8 2 8 6}$ \\
marriage7 & 0.4262 & -0.0729 & 0.2443 & 0.4467 & 0.4089 & $\mathbf{0 . 8 1 2 0}$ \\
\hline \hline HT19
\end{tabular}

For HTMT criterion, the threshold value of the ratio of correlation is between 0.85 to 0.90 (Henseler et al., 2015). Lower ratios of correlation indicate that each construct is sufficiently distinct from each other. Table 6 indicates all the ratios of correlations to be below 0.85 . 
Table 6: Discriminant validity: Heterotrait-monotrait (HTMT) criterion

\begin{tabular}{llllll}
\hline \hline Construct & $\mathbf{1}$ & $\mathbf{2}$ & $\mathbf{3}$ & $\mathbf{4}$ & $\mathbf{5}$ \\
\hline 1. ATD & & & & & \\
2. ATM & 0.5385 & & & & \\
3. FL & 0.3785 & 0.6837 & & & \\
4. SI & 0.2067 & 0.4938 & 0.5264 & & \\
5. FG & 0.3691 & 0.5790 & 0.8702 & 0.4992 & \\
6. FPM & 0.1626 & 0.5764 & 0.7733 & 0.6182 & 0.6691 \\
\hline \hline
\end{tabular}

\subsection{Hypotheses Testing}

In terms of model fit, the R-square of the relationship between the independent construct attitude towards money, attitude towards debt, financial goals and social influence and financial literacy is 0.54 . On the other hand, the R-square of the relationship between the financial literacy and financial planning for marriage is 0.461 (adjusted R-square $=0.447$ ). This indicates a strong effect size (Cohen, 1992).

The results presented in Table 7 indicate that all hypotheses are supported except for H3a. The results show that financial literacy $(\mathrm{H} 1)$, attitude towards money $(\mathrm{H} 2 \mathrm{~b})$, financial goals $(\mathrm{H} 4 \mathrm{~b})$ and social influence $(\mathrm{H} 5 \mathrm{~b})$ have a positive influence on financial planning for marriage. Attitude towards debt (H3b) however, has a negative influence on financial planning for marriage. Additionally, attitude towards money (H2a), financial goals (H4a) and social influence (H5a) have a positive influence on financial literacy.

Table 7: Structural relationships and hypotheses testing: Direct effects

\begin{tabular}{|c|c|c|c|c|c|c|}
\hline \multirow[t]{2}{*}{ " Hypotheses } & \multirow[t]{2}{*}{ Path } & \multirow[t]{2}{*}{$B$} & \multicolumn{4}{|c|}{ Standard bootstrapped results } \\
\hline & & & $\begin{array}{c}\text { Standard } \\
\text { error }\end{array}$ & $\mathrm{t}$-value & $\begin{array}{l}\mathrm{p} \text {-value (two- } \\
\text { tailed) }\end{array}$ & $\begin{array}{c}\mathrm{p} \text {-value } \\
\text { (one-tailed) }\end{array}$ \\
\hline $\mathrm{H}_{1}$ & $\mathrm{FL} \rightarrow \mathrm{FPM}$ & 0.3809 & 0.0983 & 3.8727 & 0.0001 & 0.0001 \\
\hline $\mathrm{H}_{2 \mathrm{a}}$ & $\mathrm{ATM} \rightarrow \mathrm{FL}$ & 0.2419 & 0.0604 & 4.0083 & 0.0001 & 0.0000 \\
\hline $\mathrm{H}_{2 \mathrm{~b}}$ & $\mathrm{ATM} \rightarrow \mathrm{FPM}$ & 0.1497 & 0.0641 & 2.3347 & 0.0198 & 0.0099 \\
\hline $\mathrm{H}_{3 \mathrm{a}}$ & $\mathrm{ATD} \rightarrow \mathrm{FL}$ & 0.0222 & 0.0536 & 0.4132 & 0.6795 & 0.3398 \\
\hline $\mathrm{H}_{3 \mathrm{~b}}$ & $\mathrm{ATD} \rightarrow \mathrm{FPM}$ & -0.1359 & 0.0588 & -2.3091 & 0.0211 & 0.0106 \\
\hline $\mathrm{H}_{4 \mathrm{a}}$ & $\mathrm{FG} \rightarrow \mathrm{FL}$ & 0.5668 & 0.0558 & 10.1632 & 0.0000 & 0.0000 \\
\hline $\mathrm{H}_{4 \mathrm{~b}}$ & $\mathrm{FG} \rightarrow \mathrm{FPM}$ & 0.1585 & 0.0807 & 1.9638 & 0.0498 & 0.0249 \\
\hline $\mathrm{H}_{5 \mathrm{a}}$ & $\mathrm{SI} \rightarrow \mathrm{FL}$ & 0.0857 & 0.0537 & 1.5946 & 0.1111 & 0.0558 \\
\hline $\mathrm{H}_{5 \mathrm{~b}}$ & $\mathrm{SI} \rightarrow \mathrm{FPM}$ & 0.2183 & 0.0620 & 3.5229 & 0.0004 & 0.0002 \\
\hline
\end{tabular}

The results presented in Table 8 indicate that the indirect effect of financial literacy on financial planning for marriage for attitude towards money is 0.0921, which can be considered sizeable as the value is greater than 0.08 (Hair, Black, Babin, \& Anderson, 2010). However, the total effect 
(path ATM $\rightarrow$ FPM) is lower (0.2418) than the direct effect (after accounting for financial literacy) of attitude towards money on financial planning for marriage. The value of Cohen's $f^{2}$ for the former is 0.03 , indicating a weak effect size. This indicates that financial literacy partially mediates the relationship between attitude towards money and financial planning for marriage, albeit with a relatively weak model fit.

Similarly, the indirect effect of financial literacy on financial planning for marriage for financial goals is 0.2159 , which can be considered sizeable as the value is greater than 0.08 (Hair et al., 2010). However, the total effect (path FG $\rightarrow$ FPM) is lower (0.3744) than the direct effect (after accounting for financial literacy) of financial goals on financial planning for marriage. The value of Cohen's $f^{2}$ for the former is 0.0240 , indicating a weak effect size. This indicates that financial literacy partially mediates the relationship between financial goals and financial planning for marriage. Figure 2 summarises the structural model in a path diagram.

Table 8: Path diagram $\rightarrow$ Effect overview

\begin{tabular}{ccccc}
\hline \hline Effect & $\boldsymbol{\beta}$ & Indirect effect & Total effect & Cohen's $\boldsymbol{f}^{2}$ \\
\hline FL $\rightarrow$ FPM & 0.3809 & & 0.3809 & 0.1237 \\
$\mathrm{ATM} \rightarrow$ FL & 0.2419 & & 0.2419 & 0.0965 \\
$\mathrm{ATM} \rightarrow$ FPM & 0.1497 & 0.0921 & 0.2418 & 0.0287 \\
$\mathrm{ATD} \rightarrow$ FL & 0.0222 & & 0.0222 & 0.0009 \\
$\mathrm{ATD} \rightarrow$ FPM & -0.1359 & 0.0084 & -0.1274 & 0.0300 \\
FG $\rightarrow$ FL & 0.5668 & & 0.5668 & 0.5619 \\
FG $\rightarrow$ FPM & 0.1585 & 0.2159 & 0.3744 & 0.0240 \\
SI $\rightarrow$ FL & 0.0857 & & 0.0857 & 0.0141 \\
SI $\rightarrow$ FPM & 0.2183 & 0.0326 & 0.2510 & 0.0770 \\
\hline \hline
\end{tabular}

Figure 2: Structural path diagram 


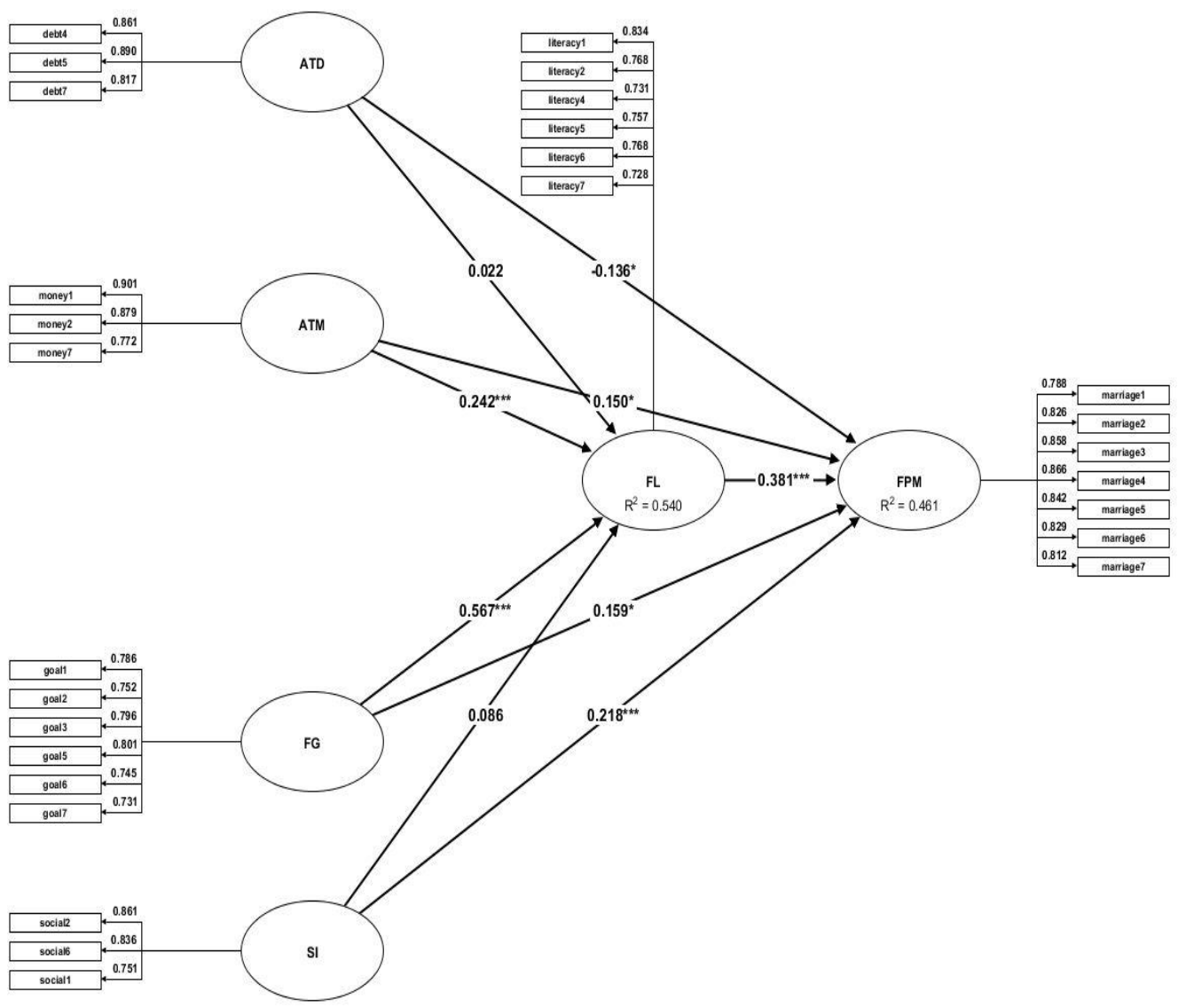

\subsection{Discussion of findings}

The current study found that the positive influence of an individual's attitude towards money, measured as power-prestige, on financial literacy indicates that materialistic individuals are more likely to believe in the importance of financial knowledge. This reinforces past research that found materialistic individuals less likely to believe themselves as financially competent and have to be financially independent (Garðarsdóttir \& Dittmar, 2012; Stone, Wier, \& Bryant, 2008). Due to the temporal euphoria of material possessions, materialistic individuals were also found to be less happy (Christopher, Saliba, \& Deadmarsh, 2010; Karabati \& Cemalcilar, 2010). Hence, the search for longer-term financial satisfaction may make financial literacy appealing to them.

In addition, the positive statistical significance of financial goals and social influence on financial literacy and financial planning for marriage corroborates past findings (Danes \& Yang, 2014; Kym, 2012; Mandell \& Klein, 2007). The current study reported an a priori finding on the weak partial mediating effect of financial literacy on the relationships between attitude towards money and financial planning for marriage, and between financial goals and financial planning for 
marriage. In this regard, past research posited that the perception and mastery of financial literacy among Malaysians are often misaligned (Murugiah, 2015). In terms of social influence, Malaysia is a collectivistic culture characterised by closely-knit membership in families, extended families and other relationships (Hofstede, Hofstede, \& Minkov, 2010). Decisions are often made in consultation with the in-group. Within the marriage context, loss of "face" could occur if an individual fails to adhere to wedding customs and live up to social expectations. This may lead couples to seek informal counsel from elders, family members and friends regarding financial planning.

Finally, the attitude towards debt does have a significant relationship with financial literacy. This result indicates that individuals may incur debt without necessarily evaluating the consequences. This is perplexing in view of the high household debt and bankruptcy rates in Malaysia especially among those between the ages of 18 to 44 (Calvalho, Sivanandam, Rahim \& Shagar, 2018). A lackadaisical attitude towards debt without proper financial literacy implies that many Malaysians may be burdened by debts that they can ill afford. In line with this, the findings also indicate that attitude towards debt has a negative influence on financial planning for marriage. The rising costs of a wedding, easy access to credit and a desire to have a "dream wedding" may drive newlyweds to overspend (Goh, 2014; Boo, 2013).

\subsection{Implications}

\subsubsection{Wedding Planning and Financial Counselling Services}

The most common causes of divorce in Malaysia are financial conflict followed by infidelity (Kamini, 2016). Regardless of household income amount, unbridled spending and undisciplined saving habits may cause financial instability within a marriage. Since financial literacy has a significant influence on financial planning for marriage, it appears that more content on financial planning may need to be incorporated into pre-marital counselling sessions in Malaysia. Currently, marital counselling is only engaged when a problem arises within the marriage, which is addressed mainly from a psychological and emotional angle (Lembaga Penduduk dan Pembangunan Keluarga Negara (LPPKN), 2016). In terms of financial planning, a more inclusive forum comprising financial planners, wedding planners and marriage counsellors could promote open communication about the management of finances for the wedding and to set financial goals within a marriage. This could result in a more practical, customised and budgetappropriate wedding planning for couples.

There is also a need to address the issue of pre-marital debt commitment among youths to reduce marital conflicts. Many Malaysians would seek financial and credit counselling only when a major crisis arises. This study recommends that young newlyweds should seek financial counselling from Agensi Kaunselling dan Pengurusan Kredit (AKPK), the financial counselling arm of Bank Negara, even at the outset of wedding planning and marriage. It would also be a good idea for these couples to check their Central Credit Reference Information System (CCRIS) report, a database which lists all individual debts from financial institutions, and be open to each other regarding their debt positions.

\subsubsection{Consumer Financial Education}


Studies have shown that young Malaysians lack financial awareness and discipline which cannot be taken lightly (Murugiah, 2015). The high number of young Malaysians vulnerable to financial scams and bankruptcy is testament to this (Bernama, 2016; Cavalho \& Hamdan, 2015; Kaur, 2016; Shanmugam, 2016). As such, the current researchers suggest that general money management aspects (practical aspects of budgeting and saving) of financial planning can be formally introduced as part of the high school curriculum. In public universities, aspects of debt management, wedding/marriage planning, investment and retirement planning can be reinforced. This is because financial planning needs practice, so education, reinforcement and discipline need to be developed at an earlier age.

To make financial planning more engaging and less intimidating to the younger generation, innovative delivery techniques such as gamification can be adopted (Darwish, 2015; Kumar \& Addagada, 2013). In this context, financial planners, banks, academic institutions and AKPK should collaborate in research towards developing content relevant to Malaysians in encouraging young adults to embrace financial planning.

\subsubsection{Social Implications}

Past research has consistently stressed on the role of parents as financial role models. As overparenting can lead to low self-efficacy and maladjustment in children (Bradley-Geist \& Olson-Buchanan, 2014; Rutherford, 2014), parents should emphasise on developing intrinsic financial values in children as they grow to be young adults rather than acquiring temporal material possession to fuel their children's self-esteem. There should be an appropriate balance between control, provision of financial support and development of financial discipline. Parents should also realise that in this day and age, overindulging their children financially will only fuel their children's sense of entitlement and in the long run, negatively affect their own retirement planning (Rourke, 2011).

While traditions and the novelty of weddings cannot be discounted, more financial awareness is needed so as not to succumb to unaffordable wedding debts. As a family member and/or close friend of newlyweds, one should recognise the responsibility of not going overboard with wedding expectations that may place a financial burden on the newlyweds. "Face" may not mean much when one is saddled with wedding debts.

\subsection{Limitations and future research}

The sample of this study is small and limited to respondents from Klang Valley, Malaysia. Besides this, there were no demographic variables included into the study.

Future research could extend the sample to other states in Malaysia as there may be sociodemographic differences. The effects of age, gender, ethnicity and income could also be investigated. In addition, future studies could investigate other constructs such as the type and depth of financial literacy that could influence financial planning for marriage. In addition, different types of money management styles within a marriage could also be evaluated in the context of urban and rural households in Malaysia. 


\section{CONCLUSION}

One of the hallmarks of a happy marriage is financial well-being and satisfaction which require a great deal of commitment towards proper financial planning. However, finance is usually a taboo topic to discuss. With the high level of indebtedness in many young adults and the rising divorce rates, financial planning for marriage is a social and economic area that warrants greater research in Malaysia. This study fills a theoretical knowledge gap in financial planning for marriage research in Malaysia by suggesting an exploratory PLS-SEM model comprising financial literacy, attitude towards money, attitude towards debt, financial goals and social influence. The implications of this study include the need for a more pro-active approach to pre-marital financial planning, an earlier introduction of financial planning education and a suggestion for more practical alternatives to fulfill social expectations in the context of marriages.

\section{ACKNOWLEDGEMENTS}

The authors acknowledge Dr Sajad Rajaei, Senior Lecturer of Digital Marketing of University of Worchester, United Kingdom (s.rezaei@worc.ac.uk) and Ms Lee Yen May, a former undergraduate at Taylor's University Business School, Malaysia for their contributions in this research.

\section{REFERENCES}

Azjen, I. (1991). The theory of planned behaviour. Organizational Behavior and Human Decision Procsses, 50, 179-211.

Bacon, P. M., Conte, A., \& Moffatt, P. G. (2014). Assortative mating on risk attitude, Theory and Decision, 77(3), 389-401.

Baker, W. E., \& Jimmerson, J. B. (1992). The sociology of money. The American Behavioural Scientist, 35(6), 678-694.

Bank Negara Malaysia. (2017). Avoid becoming a victim. Retrieved from http://www.bnm.gov.my/microsites/fraudalert/02_avoid.htm

Becker, G. S. (1973). A theory for marriage: Part 1, The Journal of Political Economy, 81(4), 813-846.

Becker, G. S. (1974). A theory of marriage. In T. W. Schultz (Ed.), Economics of the family: Marriage, Children and Human Capital (pp. 299-351). Chicago: Chicago University Press.

Bernama. (2016, October 8). 22,663 young Malaysians declared bankrupt since 2011, says financial planning council. New Straits Times. Retrieved from http://www.nst.com.my/news/2016/10/178983/22663-young-malaysians-declaredbankrupt-2011-says-financial-planning-council

Boo, S. L. (2013, December 24). Till debt do us part. The Malay Mail. Retrieved from http://www.themalaymailonline.com/malaysia/article/till-debt-do-us-part

Bradley-Geist, J., \& Olson-Buchanan, J. B. (2014). Helicopter parents: an examination of the correlates of over-parenting of college students. Education and Training, 56(4), 314328. 
Britt, S., Grable, J. E., Goff, B. S. N., \& White, M. (2008). The influence of perceived spending behaviours on relationship satisfaction., Financial Counselling and Planning, 19(1), 3143.

Britt, S. L., \& Huston, S. J. (2012). The role of money arguments in marriage. Journal of Family Economic Issues, 33(4), 464-476.

Britt, S. L., Hill, J., LeBaron, A., Lawson, D. R., \& Bean, R. A. (2017). Tightwads and Spenders: Predicting financial conflict in couple relationships, Journal of Financial Planning, $30(5), 36-42$.

Brown, J., \& Woodruffe-Brown, H. (2015). Exploring emotions and irrationality in attitude towards indebtedness: Individual perspectives of UK payday loan consumption. Journal of Financial Services Marketing, 20(2), 107-121.

Carter, M. (2006). Why clients don't stick with the plan: Emotional barriers about money and how advisors can help. Journal of Financial Planning, 19(8), 52-59.

Calvalho, M., Sivanandam, H., Rahim, R., \& Shagar, L. K. (2018, August 15). Almost 65k Malaysian youth declared bankrupt since 2013. The Star. Retrieved from https://www.thestar.com.my/news/nation/2018/08/15/almost-65k-malaysian-youthdeclared-bankrupt-since-2013/\#OiU0Ojt12tTwuRqC.99

Calvalho, M., \& Hamdan, N. (2015, June 22). Becoming bankrupt before 35. The Star. Retrieved from https://www.thestar.com.my/news/nation/2015/06/22/becoming-bankrupt-before35-worrying-trend-of-about-25000-gen-y-msians-in-debt-over-the-last-five-ye/

Christopher, A. N., Saliba, L., \& Deadmarsh, E. J. (2010). Materialism and well-being: The mediating effect of locus of control. Personality and Individual Differences, 46(7), 682686.

Chung, Y., \& Park, Y. (2014). The effects of financial education and networks on business students' financial Literacy. American Journal of Business Education, 7(3), 229-236.

Ciccoletto, C. (2009). Can personal financial planning save us from bubbles? Journal of Financial Planning, 22(1), 38-40.

Cohen, J. (1992). A power primer. Psychological Bulletin, 112(1), 155-159.

Cropanzano, R., \& Mitchell, M. S. (2005). Social Exchange Theory: An interdisciplinary review. Journal of Management, 31(6), 874-900.

Danes, S. M., \& Yang, Y. (2014). Assessment of the use of theories within the Journal of Financial Counseling and Planning and the contribution of the family socialization conceptual model. Journal of Financial Counseling and Planning, 25(1), 53-68.

Darwish, N. (2015, September). Gamification a game-changer when it comes to retirement education. Canadian HR Reporter, 28(14). Retrieved from https://www.hrreporter.com/article/25283-gamification-a-game-changer-when-it-comesto-retir/

Department of Statistics Malaysia (2014). Statistics of Household Income \& Expenditure 2014. Retrieved from https://newss.statistics.gov.my/newss-portalx/ep/epFreeDownload ContentSearch.seam?cid=164494

Dew, J. (2011). The association between consumer debt and the likelihood of divorce. Journal of Family Economic Issues, 32(4), 554-565.

Durvasula, S., \& Lynsonski, S. (2010). Money, money, money - how do attitudes toward money impact vanity and materialism- the case of young Chinese consumers. Journal of Consumer Marketing, 27(2), 169-179.

Furnham, A. (2014). The new psychology of money. Sussex, UK: Routledge-Taylors \& Francis. 
Garðarsdóttir, R. B., \& Dittmar, H. (2012). The relationship of materialism to debt and financial well-being: The case of Iceland's perceived prosperity, Journal of Economic Psychology, 33(3), 471-481.

Godwin, D. D. (1996). Newlywed couples' debt portfolios: Are all debts created equally? Association for Financial Counseling and Planning Education, 7, 57-69.

Goh, L. (2014, January 12). Till debt do us part The Star Online. Retrieved from http://www.thestar.com.my/news/nation/2014/01/12/till-debt-do-us-part/

Gollwitzer, P. M., \& Wicklund, R. A. (1982). Admission of failure and symbolic selfcompletion: Extending Lewinian Theory. Journal of Personality and Social Psychology, 43(2), 358-371.

Grinstead, M. L., Mauldin, T., Sabia, J. J., Koonce, J., \& Plamer, L. (2011). Savings for success: Financial education and savings goal achievement in individual development. Journal of Financial Counseling and Planning, 22(2), 28-77.

Hair, J. F., Black, W. C., Babin, B. J., \& Anderson, R. E. (2010). Multivariate Data Analysis: A Global Perspective ( $7^{\text {th }}$ ed.). USA: Pearson.

Hair, J. F., Ringle, C. M., \& Sarstedt, M. (2011). PLS-SEM: Indeed a silver bullet. Journal of Marketing Theory and Practice, 19(2), 139-152.

Henager, R., \& Cude, B. J. (2016). Financial literacy and ling and short term financial behavior in different age groups. Journal of Financial Counseling and Planning, 27(1), 3-19.

Henseler, J. (2018). Partial least squares path modeling: Quo vadis? Quality \& Quantity, 52(1), $1-8$.

Henseler, J., Ringle, C. M., \& Sinkovics, R. R. (2009). The use of partial least squares path modeling in international marketing. In R. R. Sinkovics \& P. N. Ghauri (Eds.), New Challenges to International Marketing - Advances in International Marketing (pp. 277-319). UK: Emerald Group Publishing Limited.

Henseler, J., Ringle, C. M., \& Sarstedt, M. (2015). A new criterion for assessing discriminant validity in variance-based structural equation modeling. Journal of the Academy of Marketing Science, 43(1), 115-135.

Higgins, E. T. (1987). Self-discrepancy: A theory relating self and affect. Psychological Review, 94(3), 319-340.

Hofstede, G., Hofstede, G. J., \& Minkov, M. (2010). Cultures and Organizations: Software of the Mind - Revised and Expanded ( $3^{\text {rd }}$ ed.). New York, USA: McGraw-Hill.

Ho, J. T. S., Ang, C. E., Loh, J., \& Ng, I. (1998). A preliminary study of kiasu behaviour — is it unique to Singapore? Journal of Managerial Psychology, 13(5/6), 359-370.

Hussain, I., \& Sajjad, S. (2016). Significance of financial literacy and its implications: A discussion. Journal of Business Strategies, 10(2), 141-154.

Idris, N. H., Yazid, Z., A., Faique, F. A., Daud, S., Ismail, S. Bakri, M.H., \& Taib, N. M. (2016). Financial literacy and debt burden among Malay youth workers in Malaysia, Advance Science Letters, 22(12), 4288-4292.

Ironfield-Smith, C., Keasey, K., Summers, B., Duxbury, D., \& Hudson, R. (2005). Consumer debt in the UK: Attitudes and implications. Journal of Financial Regulation and Compliance, 13(2), 132-141.

Ismail, S., Serguieva, A., \& Singh, S. (2011). Integrative model of students' attitude to educational loan repayment: A structural modeling approach. Journal of International Education in Business, 4(2), 125-140. 
Jay, B. N. (2019, May 25). Financial issues biggest cause of divorce in Malaysia. The New Straits Times Online. Retrieved from https://www.nst.com.my/news/nation/2019/05/491331/ financial-issues-biggest-cause-divorce-malaysia

Jiang, Q., Zhang, Y., \& Sànchez-Barricarte, J. J. (2015). Marriage expenses in rural China. The China Review, 15(1), 207-236.

Joflin, F. (2017). 7 money sucking scams Malaysians keep falling for. Retrieved from https://www.comparehero.my/blog/scams-malaysians-falling-for

Johari, F. (2014, December 4). Agama vs adat: Perkara apa yang tak perlu sebenarnya dalam perkahwinan? Says.com. Retrieved from http://says.com/my/seismik/share-agama-vsadat-perkara-apa-yang-tak-perlu-sebenarnya-dalam-perkahwinan

Joo, S., \& Grable, J. E. (2004). An exploratory framework for the determinants of financial satisfaction. Journal of Family and Economic Issues, 25(1), 25-50.

Kamal, S., Chu, S., \& Pedram, M. (2013). Materialism, attitudes, and social media usage and their impact on purchase intention of luxury fashion goods among American and Arab young generations. Journal of Interactive Marketing, 13(1), 27-40.

Kamini, R. S. (2016). Why Malaysian couples get divorced. The Rakyat Post. Retrieved from http://www.therakyatpost.com/life/wellness/2016/01/13/why-malaysian-couples-getdivorced/

Kapoor, J. K., Dlabay, L. R., \& Hughes, J. J. (2012). Personal Finance $\left(11^{\text {th }}\right.$ ed.). New York, USA: McGraw Hill Education.

Karabati, S., \& Cemalcilar, Z. (2010). Values, materialism, and well-being: A study with Turkish university students. Journal of Economic Psychology, 31(4), 624-633.

Kaur, M. (2016). More young M'sians falling prey to forex schemes. Free Malaysia Today. Retrieved from http://www.freemalaysiatoday.com/category/nation/2016/07/13/moreyoung-msians-falling-prey-to-forex-schemes/

Keown, A. (2014). Personal finance: Turning money into wealth (6 ${ }^{\text {th }}$ ed.). UK: Pearson Education Ltd.

Kerkmann, B. C., Lee, T. R., Lown, J. M. \& Allgood, S. M. (2000). Financial management, financial problems and marital satisfaction among recently married university students, Financial Counseling and Planning, 11(2), 55-65.

Kenney, C. T. (2006). The power of the purse: Allocative systems and inequality in couple households. Gender \& Society, 20(3), 354-381.

Kim, J., Gutter, M.S. \& Spangler, T. (2017). Review of family decision making: Suggestions for future research and implications for financial education, Journal of Financial Counselling and Planning, 28(2), 253-267.

Kolb, D. A. (1984). Experiential learning: experience as the source of learning and development. New Jersey, USA: Prentice Hall.

Kumar, S. F. P., \& Addagada, T. (2013). Gamification: Play banking. Global Finance, February 2013, 14-15. Retrieved from https://d2tyltutevw8th.cloudfront.net/media/document /sponsored-map-gamification-play-banking-1403321396.pdf

Kym, I. (2012). The financial life well-lived: psychological benefits of financial planning. Australasian Accounting Business \& Finance Journal, suppl. Special Issue on Financial Planning, 6(4), 47-59.

Lau, K. (2014). How to plan a saving for your wedding, to save you from wedding day misery. KCLau.com Personal Finance and Money Tips. Retrieved from https://kclau.com/blogging/saving-for-wedding/ 
Locke, E. A. (1968). Toward a theory of task motivation and incentives. Organizational Behavior and Human Performance, 3(2), 157-189.

Locke, E. A., \& Latham, G. P. (2002). Building a practically useful theory of goal setting and task motivation: A 35 year odyssea. American Psychologist, 57(9), 705-717.

Loftus, M. (2004). Till debt do us part. Psychology Today, 37(6), 42-52.

Loke, Y. K. (2013). Living beyond one's means: evidence from Malaysia. Journal of Consumer Marketing, 23(6), 335-343.

Lembaga Penduduk dan Pembangunan Keluarga Negara (LPPKN) (2016). Family and marriage counseling services. Retrieved from http://www.lppkn.gov.my/index.php/en/familydevelopment-services/173-pk0008.html

Mandell, L., \& Klein, L. S. (2007). Motivation and financial literacy. Financial Services Review, $105-116$.

Murugiah, L. (2015). The level of understanding and strategies to enhance financial literacy among Malaysians. International Journal of Economics and Financial Issues, 6(23), $130-139$.

Nash, S. N. (2008). Marrying for money. Black Enterprise, 38(8), 81-86.

Nga, K. H., Yong, H. L., \& Sellappan, R. D. (2009). A study of financial awareness among youths. Young Consumers, 11(4), 277-290.

Nga, K. H., \& Yeoh, K. K. (2015). Affective, social and cognitive antecedents of attitude towards money among undergraduate students: A Malaysian study. Pertanika Journal of Social Science \& Humanities, 23(S), 161-180.

Nunnally, J. C., \& Bernstein, I. H. (1994). Psychometric Theory ( $3^{\text {rd }}$ ed.). NY, USA: McGraw Hill.

O'Loughlin, D., \& Szmigin, I. (2016). "I'll always be in debt": Irish and UK student behaviour in a credit led environment. Journal of Consumer Marketing, 23(6), 335-343.

Painter, M. A., \& Vespa, J. (2012). The role of cohabitation in asset and debt accumulation during marriage. Journal of Family Economic Issues, 33(4), 491-506.

Patsiaouras, G., \& Fitchett, J. A. (2012). The evolution of conspicuous consumption. Journal of Historical Research in Marketing, 4(1), 154-176.

Pattarin, F., \& Cosma, S. (2012). Psychological determinants of consumer credit: The role of attitudes. Review of Behavioral Finance, 4(2), 113-129.

Penman, S. (2008). Spending their way to adulthood: consumption outside the nest. Young Consumers, 9(3), 155-169.

Robbins, A. (2017). Unshakable: Your guide to financial freedom. UK: Simon \& Schuster.

Rourke, K. S. (2011). You owe me: examining a generation of entitlement. Inquiries Journal, 3(1), 1.

Rutherford, M. B. (2014). The social value of self-esteem. Society, 48(5), 407-412.

Sari, M., \& Rofaida, R. (2011). Factors Affecting the behaviour of university community to use credit card, International Research Journal of Business Studies, 4(3), 217-228.

Shah, A. (2016, July 25). Malaysians lost more than RM100m to get-rich-quick schemes this year. New Straits Times. Retrieved from http://www.nst.com.my/news/ 2016/07/160533/malaysians-lost-more-rm100m-get-rich-quick-schemes-year

Shahab, A., Husin, M., \& Husin, N. (2017). Intention to family Takaful adopton: A Review theory and empirical work. International Journal of Organizational Leadership, 6(3), 373-384.

Shanmugam, M. (2016, July 16). Forex scheme woes. The Star. Retrieved from http://www.thestar.com.my/business/business-news/2016/07/16/forex-scheme-woes/ 
Shih, T., \& Ke, S. (2013). Determinants of financial behavior: insights into customer money attitudes and financial literacy. Service Business, 8(2), 217-238.

Shockey, S. S., \& Seiling, S. B. (2004). Moving into action: application of the transtheoretical model of behavior change to financial education. Financial Counseling and Planning, $15(1), 41-52$.

Skogrand, L., Johnson, A. C., Harrocks, A. M., \& DeFrain, J. (2011). Financial management practices of couples with great marriages. Journal of Family Economic Issues, 32(1), 27-35.

Stone, D. N., Wier, B., \& Bryant, S. M. (2008). Reducing materialism through financial literacy. The CPA Journal. Retrieved from http://selfdeterminationtheory.org/SDT/ documents/2008_StoneWierBryant_CPAJ.pdf

Sunderasen, S. D., Rahman, M. S., Othman, N. S., \& Danaraj, J. (2016). Impact of financial literacy, financial socialization agents and parental norms on money management. Journal of Business Quarterly, 8(1), 139-153.

Tang, N., \& Peter, P. C. (2015). Financial knowledge acquisition among the young: The role of education, financial experience, and parent's experience. Financial Services Review, 24, 119-137.

Taylor, C. (2014, March 28). The last taboo: Why nobody talks about money. Reuters. Retrieved from http://www.reuters.com/article/us-money-conversation-idUSBREA2Q1UN2014 0327

Treas, J., \& Dai, T. (2012). How couples manage the household: Work and power in crossnational perspective. Journal of Family Issues, 33(8), 1088-1116.

Tse, A. Y. H. (2015). To be or not to be superstitious., Mapping the Spectrum: Current and Emerging Perspectives in Linguistics, Literature and Culture, Procedia-Social and Behavioural Sciences, 208, 5-12.

Vroom, V. H. (1964). Work and motivation. New York: Wiley.

Xiao, J. J., Chen, C., \& Chen, F. (2014). Consumer financial capability and financial satisfaction. Social Research Indicators, 118(1), 415-432.

Xiao, J. J., Tang, C., Serido, J., \& Shim, S. (2011). Antecedents and consequences of risky credit behaviour among college students: Application and extension of the theory of planned behaviour, Journal of Public Policy and Marketing, 30(2), 239-245.

Yamauchi, K. T., \& Templar, D. L. (1982). The development of a money attitude scale. Journal of Personality Assessment, 46(5), 522-528.

Young, M. C., \& O’Neill, B. M. (1992). Mind over money: The emotional aspects of financial decisions. Journal of Financial Planning, 5(1), 32-38.

Yusof, S. A. \& Duasa, J. (2010). Household decision-making and expenditure patterns of married men and women in Malaysia., Journal of Family and Economic Issues, 31, 371-381.

Yusof, S. A. (2015). Household bargaining, financial decision making and risk tolerance, International Journal of Business and Society, 16(2), 221-236.

Zaid, M. A. (2017, January 5). 121,673 guna khidmat AKPK tahun lalu. Utusan. Retrieved from http://www.utusan.com.my/bisnes/ekonomi/121-673-guna-khidmat-akpk-tahun-lalu1.428398

Zissimopoulos, J. M., Karney, B. R., \& Rauer, A. J. (2015). Marriage and economic well being at older ages. Review of Economics of the Household, 13(1), 1-35. 